\title{
Targeting MRP4 expression by anti-androgen treatment reverses MRP4-mediated docetaxel resistance in castration-resistant prostate cancer
}

\author{
YUN-FEI LI* ${ }^{*}$, HUI-HUA JI ${ }^{*}$, ZHENG-LONG ZHANG, TAO-TAO ZHANG, WEI GAN and SHAO-FENG ZHANG \\ Department of Urology, Renmin Hospital, Hubei University of Medicine, Shiyan, Hubei 442000, P.R. China
}

Received February 18, 2016; Accepted February 3, 2017

DOI: $10.3892 / \mathrm{ol} .2017 .6357$

\begin{abstract}
It has been demonstrated that docetaxel (DTX) may improve the overall survival of patients with castration-resistant prostate cancer (CRPC). However, its effectiveness is limited with time, and tumor escape is eventually inevitable. DTX resistance is the main reason for the failure of chemotherapy for CRPC. In the present study, the expression status of multidrug resistance protein 4 (MRP4) in DTX-resistant prostate cancer cells was investigated, and it was explored whether anti-androgen treatment may inhibit MRP4 expression and overcome DTX resistance. DTX-resistant C4-2/D cells were established by exposing DTX-sensitive C4-2/S cells to gradually increasing concentrations of DTX. MRP4 gene expression and the effect of androgen signaling on its expression were assessed by reverse transcription-polymerase chain reaction and western blotting. Intracellular and extracellular concentrations of DTX were detected by high-performance liquid chromatography. Anti-androgen treatment effects on DTX sensitivity were determined by a clonogenic test and an MTT cytotoxicity assay. MRP4 was overexpressed in C4-2/D cells, while its expression was barely detectable in C4-2/S cells. MRP4 expression levels were elevated in C4-2/D cells by dihydrotestosterone, whereas they were blocked by anti-androgen bicalutamide (BKL) treatment. Intracellular and extracellular DTX concentrations in C4-2/D cells were associated with MRP4 levels. The downregulation of MRP4 by BKL increased the intracellular concentration of DTX in C4-2/D cells and re-sensitized C4-2/D cells to DTX. These results indicated that overexpression of MRP4 mediates acquired DTX resistance, and suggest that targeting MRP4 expression
\end{abstract}

Correspondence to: Professor Shao-Feng Zhang, Department of Urology, Renmin Hospital, Hubei University of Medicine, 76 Chaoyang Road, Shiyan, Hubei 442000, P.R. China

E-mail: lyf694110@aliyun.com

*Contributed equally

Key words: castration-resistant prostate cancer, multidrug resistance protein 4 , docetaxel, bicalutamide, androgen by anti-androgen treatment may reverse DTX-resistant prostate cancer cells to DTX chemotherapy.

\section{Introduction}

The management of castration-resistant prostate cancer (CRPC) currently remains a challenge (1). Docetaxel (DTX) induces apoptotic cell death by stabilizing $\beta$-tubulin, thereby blocking mitotic cell division and inhibiting androgen receptor nuclear translocation (2). DTX is the standard first-line drug for the treatment of CRPC, however, only $\sim 48 \%$ of patients respond to DTX, and acquired drug resistance rapidly develops in DXT chemotherapy (3). Patients with DTX-resistant or -progressive CRPC previously treated with DTX, cabazitaxel (4), abiraterone acetate (5) enzalutamide (6), sipuleucel-T (7) and radium 223-dichloride (8) have shown an improvement in overall survival time over the placebo group in phase III clinical trials. However, recent cost-effectiveness analyses for patients with CRPC have shown unfavorable results for these new drugs, since these drugs are not affordable to numerous patients, particularly in less developed countries (9). Thus, cost-effective therapeutic strategies are urgently required for the management of CRPC.

Multiple mechanisms are involved in the development of DTX resistance in CRPC. Firstly, multi-drug resistance 1 (MDR1) promotes drug efflux through a P-glycoprotein pump, and prostate cancer cells with increased MDR1 expression demonstrate markedly reduced intracellular concentrations of DTX $(10,11)$. Secondly, the modulation and phenotype changes of microtubules (the primary target of DTX) are associated with reduced response rates in patients receiving DTX-based chemotherapy (12). The accumulation of certain $\beta$-tubulin isotypes ( $\beta$ III-tubulin and $\beta$ IV-tubulin) increases the dynamic activity of microtubules, thereby decreasing the efficacy of DTX (13). In addition, $\beta$-tubulin mutations (T26A, A595G and F270I) lead to alterations in the microtubule-binding site of DTX and reduce the efficacy of DTX (14). Furthermore, the overexpression of B-cell lymphoma-2 and the loss of p53 function have been shown to contribute to the resistance of CRPC to DTX (15). Finally, the high activity of drug-detoxifying proteins, including glutathione-S-transferase and cytochrome P450 3A, increases DTX metabolism $(16,17)$. Accordingly, several inhibitors that target these mechanisms have been developed; however, clinical trials of these agents 
as single or combination therapies have exhibited only limited clinical efficacy $(3,18)$. Thus, the identification of new molecular mechanisms of DTX resistance and the development of novel targeted treatment strategies are urgently required for CRPC.

Multi-drug resistance protein 4 (MRP4) is a member of the MRP family, and transports a variety of molecules that are principally organic anions, including the cyclic nucleotide cyclic adenosine monophosphate, prostaglandins, dehydroepiandrosterone, bile acids and numerous drugs such as the camptothecin-11 metabolite SN-38, topotecan, methotrexate and anti-retrovirals (19). In recent years, accumulating evidence has indicated that the overexpression of MRP4 is a possible molecular mechanism for unexplained failures of chemotherapy in certain tumors (20-22). In gastric cancer, cisplatin (DDP) resistance was revealed to be associated with MRP4 overexpression, and the decrease in MRP4 expression by RNA interference reversed DDP resistance in vitro (23). Similarly, acquired resistance to methotrexate was associated with the overexpression of MRP4 in LNCaP cells, while disruption of MRP4 expression sensitized LNCaP cells to methotrexate (24). In addition, it was reported that MRP4 expression levels increased with androgen treatment, but decreased with anti-androgen treatment, in LNCaP cells (25). Furthermore, our previous study demonstrated that DTX-resistance time in patients with low testosterone levels was significantly delayed compared with that in patients with high testosterone levels (26). These data indicated that androgen levels may be associated with DTX resistance. However, the association between MRP4 and DTX resistance, and the effect of androgen on MRP4 expression in DTX-resistant prostate cancer cells remain unknown.

In the present study, DTX-resistant prostate cancer cell lines were established from prostate cancer androgen-independent C4-2 cell lines to define the association between MRP4 and DTX resistance, and to explore the effect of androgen signaling on MRP4 expression and its efflux activity.

\section{Materials and methods}

Cell lines and reagents. C4-2 cells obtained from the American Type Culture Collection (Manassas, VA, USA) were cultured in RPMI-1640 medium (Sigma-Aldrich; Merck KGaA, Darmstadt, Germany) supplemented with $10 \%$ complete fetal bovine serum (Sigma-Aldrich; Merck $\mathrm{KGaA}), 100 \mathrm{U} / \mathrm{ml}$ penicillin and $100 \mu \mathrm{g} / \mathrm{ml}$ streptomycin, and were maintained at $37^{\circ} \mathrm{C}$ in a humidified incubator with $5 \% \mathrm{CO}_{2}$. DTX (cat no., 125354-16-7) was purchased from Shanghai Sanwei Pharmaceutical Co., Ltd. (Shanghai, China). Bicalutamide (BKL; cat no., 144701-48-4) and dihydrotestosterone (DHT; cat no., 521-18-6) were purchased from Sigma-Aldrich (Merck KGaA). Antibodies against MRP4 (cat no., \#ab15598) and GAPDH (cat no., \#ab181603) were obtained from Abcam (Cambridge, MA, USA). Plasmid pDONR223-based full-length androgen receptor constructs [human androgen receptor (AR) complementary DNA (cDNA) clone, AR (NM_000044)] and lentiviral vector-based MRP4 short hairpin RNA (shRNA) constructs were purchased from Chongqing Youbao Biotechnology Co., Ltd. (Chongqing, China).
DTX-resistant culture. Cells were seeded onto 6-well plates at $2 \times 10^{5}$ cells $/ \mathrm{ml}$ and maintained at $37^{\circ} \mathrm{C}$ for 2 weeks. DTX-resistant cells were generated from parental C4-2 cells by gradually increasing DTX concentrations $(0,5,10,20$ or $40 \mathrm{nM}$ ) in the culture medium. Cells that survived the maximum concentration of DTX $(40 \mathrm{nM})$ were selected for subsequent analysis and were referred to as C4-2/D cells. Parental cells were passaged alongside DTX-treated cells and were referred to as C4-2/S cells; these cells were used as an appropriate control. DTX-resistant and -sensitive cell lines were seeded onto 6-well plates at a density of $1 \times 10^{3}$ cells/well, then maintained at $37^{\circ} \mathrm{C}$ for $48 \mathrm{~h}$. Following treatment with or without $40 \mathrm{nM}$ DTX for 21 days, total cell numbers were counted using a ViCell Coulter counter (Beckman Coulter, Inc., Brea, CA, USA).

Experiment grouping design and treatment. C4-2/S and C4-2/D cells were divided into three groups according to the culture medium added with different drugs: Group A [PBS (+), DHT (-), BKL (-)]; group B [PBS (-), DHT (+), BKL (-)]; and group C [PBS (-), DHT (+), BKL (+)]. Cells in group A were cultured with PBS for 5 days at room temperature as a control. Group B cells were cultured at $37^{\circ} \mathrm{C}$ with $20 \mathrm{nM}$ DHT for 5 days, while group $\mathrm{C}$ cells were treated with $20 \mathrm{nM}$ DHT plus $50 \mathrm{nM}$ BKL for 5 days. In addition, in order to observe the effect of different levels of androgen on the expression of MRP4, cells were maintained for 5 days under five different concentrations of DHT (0, 5, 10, 20 and $40 \mathrm{nM})$. Medium plus drugs were replenished each day. On the sixth day, the plates were placed on a bed of ice and cells were harvested by scraping.

Semi-quantitative reverse transcription-polymerase chain reaction $(R T-P C R)$. RNA isolation was performed using TRIzol reagent (Invitrogen; Thermo Fisher Scientific, Inc., Waltham, MA, USA) and was subjected to RT using M-MLV reverse transcriptase (Fermentas; Thermo Fisher Scientific, Inc., Pittsburgh, PA, USA) following the manufacturer's protocol. The cDNA product was used for PCR $(5 \mu \mathrm{l})$, using the PCR Master Mix (Fermentas; Thermo Fisher Scientific, Inc.) and the following thermocycler settings: Initially pre-denatured at $94^{\circ} \mathrm{C}$ for $6 \mathrm{~min}$, then denatured at 40 cycles of $95^{\circ} \mathrm{C}$ for $20 \mathrm{sec}$ and annealed at $44^{\circ} \mathrm{C}$ for $30 \mathrm{sec}$. PCR products were separated by $1.5 \%$ agarose gel electrophoresis and stained with ethidium bromide. The respective forward and reverse primers used for each gene were: MRP4 forward, 5'-CAGAGTCTTCGG TTTGGT-3' and reverse, 5'-GCTTCTCGGTTACATTTC-3'; AR forward, 5'-CCTACGGCTACACTCGG-3' and reverse, 5'-CTGGCAGTCTCCAAACG-3'; and GAPDH forward, 5'-AATCCCATCACCATCTTCC-3' and reverse, 5'-AGTCCT TCCACGATACCAA-3'. GAPDH was used as control.

Clonogenic assay. C4-2/S and C4-2/D cells were treated with $50 \mu 10.2 \%$ dimethyl sulfoxide (DMSO) or different doses of DTX $(10,20$ and $40 \mathrm{nM})$ at $37^{\circ} \mathrm{C}$ for $8 \mathrm{~h}$, and $1 \times 10^{3}$ cells were plated on a $100-\mathrm{mm}$ dish at $37^{\circ} \mathrm{C}$ for 21 days. Cells were fixed with $4 \%$ formaldehyde for $10 \mathrm{~min}$ and stained with $0.5 \%$ crystal violet for $30 \mathrm{~min}$ at room temperature. Colonies were counted using a ViCell Coulter counter (Beckman Coulter, Inc.). 
Cell apoptosis assay. Cell apoptosis was assayed by flow cytometry (Beckman Coulter, Inc.). Cells were harvested and re-suspended in PBS containing 2\% bovine serum albumin (Sigma-Aldrich; Merck KGaA). Following centrifugation at $620 \mathrm{x} \mathrm{g}$ at $4^{\circ} \mathrm{C}$ for $5 \mathrm{~min}$, cells were re-suspended with $500 \mu \mathrm{l}$ binding buffer [including $50 \mathrm{mmol} / 1$ sodium phosphate buffer, $0.3 \mathrm{~mol} / 1 \mathrm{NaCl}, 10 \mathrm{mmol} / 1$ imidazole ( $\mathrm{pH}$ 8.0); Chongqing Youbao Biotechnology Co.,Ltd., Chongqing, China] and mixed with $5 \mu \mathrm{l}$ of $0.5 \mathrm{mg} / \mathrm{ml}$ Annexin V-fluorescein isothiocyanate (FITC; Oncogene Research Products, La Jolla, CA, USA). Cells were then incubated with $5 \mu 1$ of $0.6 \mathrm{mg} / \mathrm{ml}$ propidium iodide (Oncogene Science; Nuclea Diagnostics Laboratories, LLC, Cambridge, MA, USA) in the dark at room temperature for 5-15 min. Apoptotic cells with positive Annexin V-FITC staining were detected by flow cytometry. All assays were performed in triplicate.

MTT assay. C4-2/S and C4-2/D cells were seeded onto 96-well plates at a density of $1 \times 10^{5}$ cells/well in quadruplicate, treated with DTX $(40 \mathrm{nM})$ and incubated at $37^{\circ} \mathrm{C}$ for $24 \mathrm{~h}$. Cell viability was evaluated with MTT (Promega Corporation, Madison, WI, USA). Briefly, $20 \mu 1$ MTT was added to the cells, which were incubated in the dark for an additional $4 \mathrm{~h}$ at $37^{\circ} \mathrm{C}$. The supernatant was then discarded and $100 \mu 1$ DMSO (Sigma-Aldrich; Merck KGaA) was added to each well to dissolve the formazan product. The absorbance of the solution was measured at a 490-nm excitation and a 520-nm emission wavelength using a microplate reader (Bio-Rad Laboratories, Inc., Hercules, CA, USA).

Plasmids and cell transfection. C4-2/D cells were transiently transfected with shRNAs specific against MRP4 or green fluorescent protein (as a vector control) using Attractene Transfection Reagent (Qiagen GmbH, Hilden, Germany). C4-2/D shMRP4- and empty vector-trnsfected stable clones were selected with $2 \mu \mathrm{g} / \mathrm{ml}$ puromycin within 14 days after transfection, and then maintained in culture medium containing $2 \mu \mathrm{g} / \mathrm{ml}$ puromycin.

Western blot analysis. Cells were washed twice with PBS buffer and lysed in radioimunnoprecipitation assay lysis buffer (50 mM Tris- $\mathrm{Cl} \mathrm{pH} 7.4,150 \mathrm{mM} \mathrm{NaCl}, 0.5 \%$ sodium deoxycholate, $1 \%$ NP-40, 0.1\% SDS, 1 mM EDTA, $100 \mathrm{mM}$ $\mathrm{NaF}, 1 \mathrm{mM} \mathrm{Na} \mathrm{VO}_{4}, 1 \mathrm{mM}$ phenylmethylsulfonyl fluoride and $2 \mu \mathrm{g} / \mathrm{ml}$ aprotinin) on ice. Total protein $(50 \mu \mathrm{g})$ was separated by $8 \%$ SDS-PAGE and transferred to polyvinylidene difluoride membranes. Membranes were blocked with 5\% nonfat milk in TBS-Tween-20 (TBST; $10 \mathrm{mM}$ Tris $\mathrm{pH} 7.4$, $150 \mathrm{mM} \mathrm{NaCl}$ and $0.1 \%$ Tween-20) at room temperature for $2 \mathrm{~h}$, and blots were probed with an anti-MRP4 antibody (dilution, 1:200; cat no. ab15598) or anti-GAPDH antibody (dilution, 1:200; cat no. ab181603; Abcam, Cambridge, MA, USA,) as a control for protein loading. Subsequent to washing with TBST, the membrane was incubated with a horseradish peroxidase-conjugated secondary antibody (dilution, 1:1,000; cat. no ab2116; Sigma-Aldrich; Merck KGaA,) for $2 \mathrm{~h}$ at room temperature. Following extensive washing with TBST, the presence of proteins was visualized by an enhanced chemiluminescence detection kit according to the manufacturer's protocol (GE Healthcare Life Sciences, Chalfont, UK).
Determination of DTX concentration inside cells and in the cell culture supernatant. C4-2/D and C4-2/S cells were incubated with $250 \mu \mathrm{l}$ medium containing $40 \mathrm{nM} \mathrm{DTX}$ at $37^{\circ} \mathrm{C}$ for $0.5,1,2,3,4,5,6,7,8,9$ or $10 \mathrm{~h}$. Following incubation, the medium at different time points was transferred into a fresh tube, diluted in $500 \mu \mathrm{l}$ PBS and subjected to high-performance liquid chromatography (HPLC). In order to determine intracellular DTX concentrations, cells were treated with $0.25 \%$ trypsin (Invitrogen; Thermo Fisher Scientific, Inc.), washed six times with PBS and resuspended in $500 \mu \mathrm{l}$ PBS. Cell samples were subsequently frozen in a refrigerator at $-60^{\circ} \mathrm{C}$ for $1 \mathrm{~h}$ and then thawed in a water bath at $37^{\circ} \mathrm{C}$ for $5 \mathrm{~min}$ to lyze the cells. Following five repetitions of the frozen-and-thaw cycle, cell lysates were collected and subjected to HPLC. In addition, in order to observe the effect of androgen on intracellular DTX concentrations in CRPC cells, cells treated with 40 nM DTX were maintained at the aforementioned time points under one of the three following conditions: Medium with PBS; medium with $20 \mathrm{nM}$ DHT; or medium with $20 \mathrm{nM}$ DHT plus $50 \mathrm{nM}$ BKL. Cell lysates were prepared as aforementioned.

HPLC was performed on a Waters SunFire C18 column (250x4.6 mm $\mathrm{mm}^{2}, 5 \mu \mathrm{m}$; Waters Corporation, Milford, MA, USA). The mobile phase consisted of water: $0.043 \mathrm{~mol} / 1$ ammonium acetate and acetonitrile (53:47). Flow rate was maintained at $1 \mathrm{ml} / \mathrm{min}$ with an injection volume of $20 \mu \mathrm{l}$. Effluents were monitored at a detection wavelength of $232 \mathrm{~nm}$.

Statistical analysis. All data are presented as the mean \pm standard deviation. Differences among multiple groups were determined using one-way analysis of variance followed by the least significant difference procedure for comparison of mean values. Student's t-tests were used to assess differences in DTX concentrations between drug-resistant and parental cells. $\mathrm{P}<0.05$ was considered to indicate a statistically significant difference. All reported P-values were two-sided. Statistical analyses were performed using SPSS 19.0 software (IBM SPSS, Armonk, NY, USA).

\section{Results}

Development and characterization of DTX-resistant prostate cancer cells. In order to determine the association between MRP4 expression and acquired DTX resistance, DTX-resistant C4-2 cells (C4-2/D) were first established from parental C4-2 (C4-2/S) cells by culturing C4-2 cells with DTX in a dose-escalation manner (3-40 nM). Following 90 days of selection, cells that survived the maximum concentration of DTX $(40 \mathrm{nM})$ were used for subsequent analysis and referred to as C4-2/D cells. In order to test the effect of DTX on the proliferation of DTX-resistant and -sensitive cells, a clonogenic ability assay was performed for C4-2/D and C4-2/S cells following treatment with increasing concentrations of DTX for $8 \mathrm{~h}$. The clonogenic ability of resistant cells was significantly increased compared with that of sensitive cells in response to DTX treatment $(\mathrm{P}<0.05)$. When DTX concentration was increased to $40 \mathrm{nM}$, there were almost no colonies formed by $\mathrm{C} 4-2 / \mathrm{S}$ cells, while the number of colonies formed by C4-2/D cells was similar to that of the untreated cells (Fig. 1A and B). In order to test the toxicity of DTX in DTX-resistant and -sensitive cells, C4-2/D and C4-2/S cells were exposed to 
$40 \mathrm{nM}$ DTX for $24 \mathrm{~h}$, and cell apoptosis was analyzed by MTT assay. DTX at a concentration of $40 \mathrm{nM}$ reduced cell viability in $\mathrm{C} 4-2 / \mathrm{S}$ cells $(\mathrm{P}<0.05)$, but had little effect on $\mathrm{C} 4-2 / \mathrm{D}$ cells (Fig. 1C).

MRP4 is overexpressed in DTX-resistant prostate cancer cells and inhibition of MRP4 expression reverses DTX resistance. MRP4 is a membrane pump involved in the efflux of chemotherapy drugs (22). In order to define the expression pattern of MRP4 in DTX-resistant and -sensitive prostate cancer cells, total RNA was isolated from C4-2/D and C4-2/S cells, and MRP4 mRNA levels were analyzed by semi-quantitative RT-PCR. As shown in Fig. 2A, MRP4 mRNA was highly expressed in C4-2/D cells, but was not detectable in C4-2/S cells. MRP4 protein expression was analyzed by western blotting in whole cell extracts of C4-2/D and C4-2/S cells. Similar to its mRNA expression, MRP4 protein was strongly expressed in C4-2/D cells (Fig. 2B). These results demonstrated that MRP4 was overexpressed in DTX-resistant cells at the mRNA and protein levels.

It was next tested whether overexpression of MRP4 leads to DTX resistance in C4-2/D cells. MRP4 protein expression was knocked down by MRP4 shRNA in C4-2/D cells (Fig. 2C), followed by treatment with DTX. As shown in Fig. 2D, inhibition of MRP4 expression by MRP4 shRNA re-sensitized C4-2/D cells to DTX treatment. These data indicated that MRP4 may be an important determinant of DTX resistance, and that inhibition of MRP4 expression reverses DTX resistance.

Androgen upregulates MRP4 expression. In our previous study, it was identified that the DTX-resistance time in CRPC patients with low testosterone levels was significantly delayed (19). In the present study, a test was performed to determine whether androgen leads to MRP4 overexpression in DTX-resistant cells. C4-2/D cells were treated with BKL or DHT, and the mRNA and protein levels of MRP4 were determined by semi-quantitative RT-PCR and immunoblotting, respectively. MRP4 mRNA levels were upregulated by DHT treatment, which was significantly prevented by the anti-androgen BKL in C4-2/D cells $(\mathrm{P}<0.05$; Fig. $3 \mathrm{~A}$ and $\mathrm{B})$. Similarly, MRP4 protein levels were increased by DHT treatment, which was significantly abolished by BKL in C4-2/D cells $(\mathrm{P}<0.01$; Fig. $3 \mathrm{C}$ and $\mathrm{D})$. C4-2/D cells were then treated with different concentrations of DHT $(0,5,10,20$ or $40 \mathrm{nM})$, and MRP4 mRNA expression was determined by semi-quantitative RT-PCR. The results revealed that DHT upregulated the mRNA expression of MRP4 in C4-2/D cells in a dose-dependent manner $(\mathrm{P}<0.05$; Fig. 3E and F). The alteration to MRP4 mRNA expression reached a peak at $20 \mathrm{nM}$ DHT; a dose of $40 \mathrm{nM}$ DHT was not indicated as statistically more effective than $20 \mathrm{nM}$. To assess whether DHT-induced overexpression of MRP4 mRNA results from increased AR levels, the mRNA and protein levels of AR were examined in C4-2/D cells treated with the different DHT concentrations as mentioned previously. The results revealed that neither the mRNA (Fig. 4A) or protein (Fig. 4B) levels of $\mathrm{AR}$ were altered following treatment of $\mathrm{C} 4-2 / \mathrm{D}$ cells with different DHT concentrations. These results demonstrated that MRP4 was upregulated by androgen and downregulated by anti-androgen treatment.
$B K L$ reverses DTX resistance in DTX-resistant prostate cancer cells. In order to examine whether BKL restores DTX sensitivity in C4-2/D cells, C4-2/D cells were treated with $40 \mathrm{nM}$ DTX and $50 \mathrm{nM}$ BKL in the presence or absence of $20 \mathrm{nM}$ DHT. As shown in Fig. 5A, MRP4 protein level was significantly upregulated upon treatment of DTX alone or in combination with DHT, which was abolished by BKL. In addition, MTT assay revealed that BKL alone had little effect on the viability of C4-2/D cells in the absence of DHT and DTX, while the combination DTX and BKL reduced the viability of C4-2/D cells by $\sim 60 \%$ in the presence of DHT (Fig. 5B). Similarly, the combination of BKL and DTX significantly induced apoptotic cell death in C4-2/D cells in the presence of DHT (Fig. 5C). Taken together, these results revealed that BKL restored DTX sensitivity in C4-2/D cells.

In order to clarify whether the BKL reversal of DTX resistance was caused by a decrease in MRP4 expression, intracellular and extracellular concentrations of DTX in C4-2/D cells following treatment with DTX in the presence or absence of DHT or in combination with BKL were determined. As shown in Fig. 5D, the cell culture supernatant concentration of DTX in C4-2/D cells was increased compared with that in C4-2/S cells. By contrast, the intracellular DTX concentration in C4-2/D cells was lower compared with that in C4-2/S cells (Fig. 5E). Notably, the intracellular DTX concentration in C4-2/D cells treated with DHT was lower than that in PBS-treated control cells. Furthermore, the intracellular DTX concentration in C4-2/D cells treated with DHT plus BKL increased compared with that in cells treated with only DHT or PBS (Fig. 5F). These data demonstrated that BKL increased the intracellular DTX concentration of DTX-resistant prostate cancer cells, indicating that BKL restores DTX sensitivity by reducing the expression of MRP4.

\section{Discussion}

DTX-based therapy is the standard first-line chemotherapy in patients with metastatic CRPC. However, tumor progression eventually occurs due to the development of resistance to DTX treatment (27). In the present study, a DTX-resistant prostate cancer C4-2/D cell line was developed from parental androgen-independent C4-2 cells, and the expression level of MRP4, as well as the association between its expression and androgen, was investigated. It was revealed that MRP4 was highly expressed and regulated by androgen in C4-2/D cells. Notably, the downregulation of MRP4 by the androgen antagonist BKL re-sensitized C4-2/D cells to DTX treatment. The present findings indicated that overexpression of MRP4 contributes to acquired DTX resistance, and indicated that targeting MRP4 expression by anti-androgen treatment is a potential approach to reverse the sensitivity of DTX-resistant prostate cancer cells to DTX chemotherapy.

The present study indicated that overexpression of MRP4 is a novel mechanism of DTX resistance in CRPC. MRP4 mRNA and protein levels were significantly increased in C4-2/D cells compared with those in C4-2/S cells, and MRP4 expression levels in C4-2/D cells were positively associated with cell growth and negatively associated with cell apoptosis. Furthermore, following DTX treatment, the DTX concentration was lower in C4-2/D cells than in C4-2/S cells. By contrast, 
A

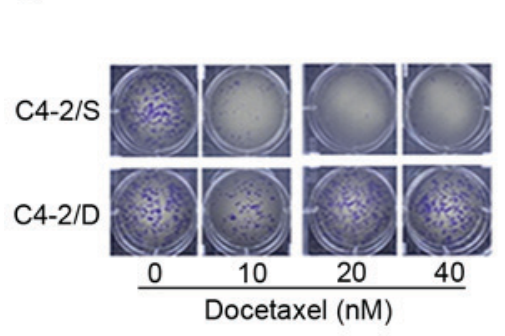

B

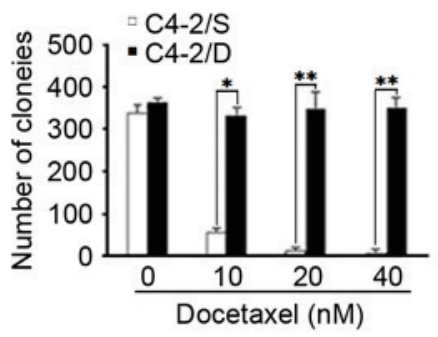

C

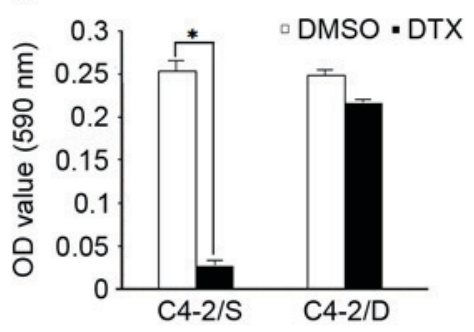

Figure 1. Effects of DTX on clonogenic ability and apoptosis in DTX-resistant (C4-2/D) and sensitive (C4-2/S) cells. (A) Effects of DTX on clonogenic ability. C4-2/S and C4-2/D cells were treated with DMSO or the indicated doses of DTX for $8 \mathrm{~h}$. Following treatment, $1 \mathrm{x} 10^{3}$ cells were placed in a 100 -mm dish with fresh medium. Visible clones were formed after 21 days. (B) The number of colonies of DTX-resistant and -sensitive cell lines was counted. (C) Toxicity of DTX in DTX-resistant (C4-2/D) and sensitive (C4-2/S) cells. C4-2/S and C4-2/D cells were treated with DTX (40 nM) and incubated for 24 h. Cell viability was then determined using an MTT assay. ${ }^{*} \mathrm{P}<0.05 ;{ }^{* *} \mathrm{P}<0.001$. DMSO, dimethyl sulfoxide; DTX, docetaxel; OD, optical density.

A
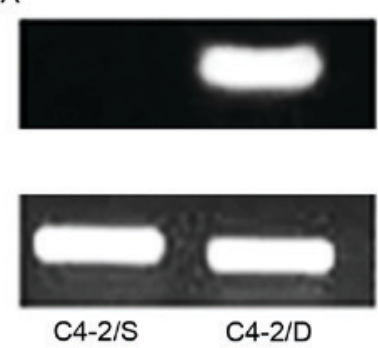

GAPDH

C

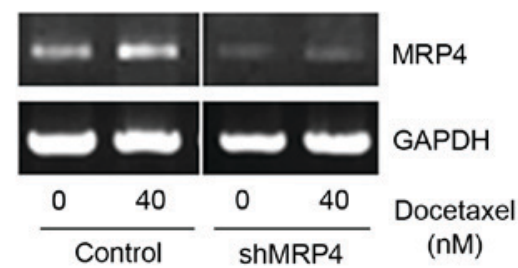

B

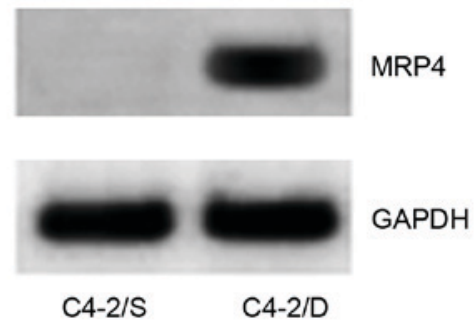

D

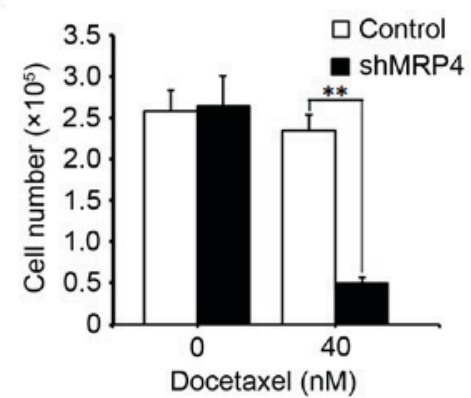

Figure 2. MRP4 is overexpressed in DTX-resistant (C4-2/D) cells and inhibition of MRP4 expression reverses DTX resistance. (A) Semi-quantitative reverse transcription-polymerase chain reaction analysis of MRP4 mRNA in C4-2/S and C4-2/D cells. (B) MRP4 protein expression was detected by western blot analysis. GAPDH served as a loading control. (C) C4-2/D cells were transfected with $2 \mu \mathrm{g}$ MRP4 shRNA (shMRP4) or control shRNA for 36 h. Western blotting revealed that shMRP4 downregulated MRP4 protein levels. (D) Downregulation of MRP4 expression re-sensitized C4-2/D cells to DTX treatment. At $36 \mathrm{~h}$ post-transfection with $2 \mu \mathrm{g}$ shMRP4 or control shRNA, C4-2/D cells were treated with vehicle or $40 \mathrm{nM}$ DTX for $24 \mathrm{~h}$ and apoptotic cell death was determined using Annexin V-fluorescein isothiocyanate staining coupled with flow cytometry. ${ }^{* *} \mathrm{P}<0.001$. MRP4, multidrug resistance protein 4; shRNA, short hairpin RNA; DTX, docetaxel.

the extracellular DTX concentration increased in C4-2/D cells compared with that in $\mathrm{C} 4-2 / \mathrm{S}$ cells. This indicated there is higher MRP4 expression in C4-2/D cells. Finally, the present results revealed that MRP4 expression levels were decreased by BKL, indicating that MRP4 is an androgen signaling-regulated gene. Accordingly, the decrease in MRP4 expression by BKL reversed the intracellular DTX concentration in C4-2/D cells and sensitized C4-2/D cells to DTX.

Another important question that arose from the present findings is how AR signaling regulates MRP4 expression. It has been reported that the binding of androgen to AR results in AR translocation into the nucleus, whereby AR indirectly binds the MRP4 promoter and promotes the transcription of the MRP4 gene (24). In addition, the non-AR signaling pathway also performs an important role in the regulation of MRP4 expression. Androgens may increase the levels of cyclic guanosine monophosphate, which has been implicated in inducing MRP4 expression (28). In addition, another study demonstrated that androgen induction of E-twenty six (ETS) translocation variant 1 , which is a member of the ETS family of transcription factors, is associated with enhanced MRP4 gene expression in liver cancer cells (29). Similarly, in the present study, it was observed that androgen induced the expression of MRP4 in DTX-resistant prostate cancer cells. However, in contrast to previous studies $(24,29)$, the present study observed that MRP4 expression exhibited a certain dose of DHT dependence under castration levels of testosterone (equivalent to $\leq 50 \mathrm{ng} / \mathrm{dl}$ of serum testosterone) (30). The effect of low levels of DHT on MRP4 expression indicates that androgen levels should be reduced as much as possible during 
A

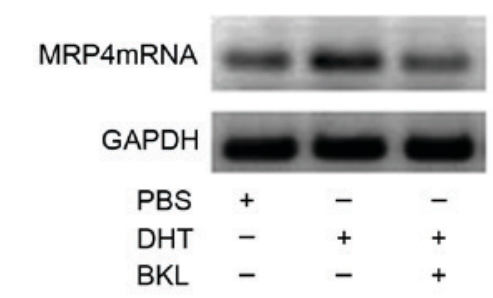

C

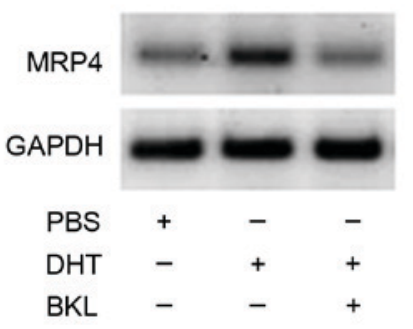

E

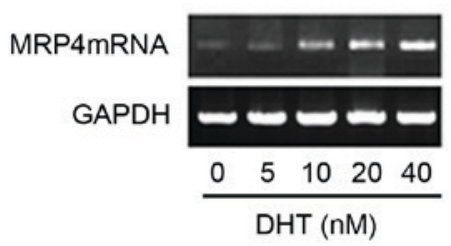

B

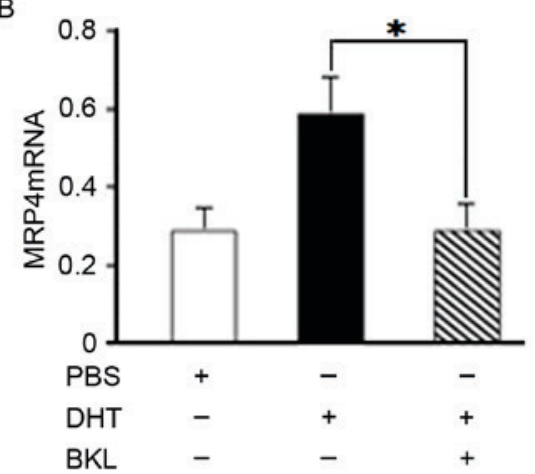

D

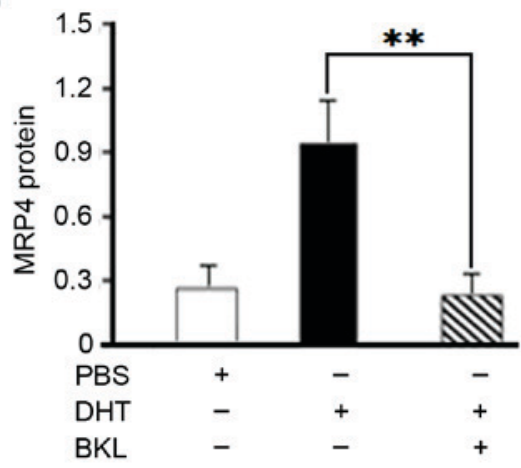

$\mathrm{F}$

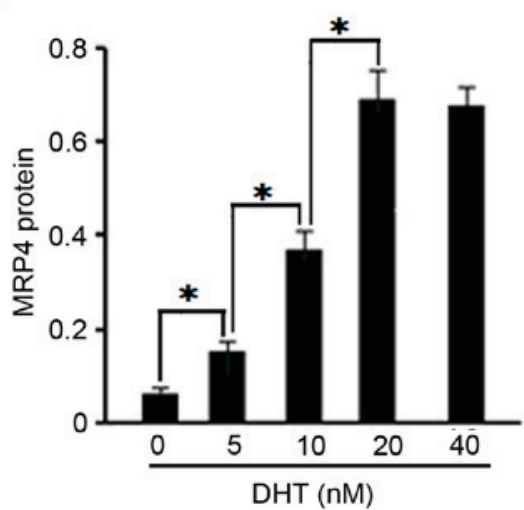

Figure 3. MRP4 mRNA and protein levels were upregulated by androgen and downregulated by anti-androgen treatment in docetaxel-resistant (C4-2/D) cells. C4-2/D cells were incubated with $20 \mathrm{nM}$ DHT, $50 \mathrm{nM}$ BKL or PBS (as a control) to assess the effect of androgen treatment on MRP4 expression. GAPDH was used as a control. (A) MRP4 mRNA expression levels were measured by semi-quantitative RT-PCR. (B) The level of MRP4 mRNA expression was analyzed with a histogram. (C) MRP4 protein levels were assessed by western blotting. (D) The level of MRP4 protein expression was analyzed with a histogram. (E) C4-2/D cells were maintained for 5 days with the indicated concentrations of DHT. MRP4 mRNA expression was measured by semi-quantitative RT-PCR and GAPDH was used as control. (F) Statistical analysis of MRP4 expression in the presence of different concentrations of DHT. ${ }^{*} \mathrm{P}<0.05 ;{ }^{* *} \mathrm{P}<0.001$. DHT, dihydrotestosterone; BKL, bicalutamide; RT-PCR, reverse transcription-polymerase chain reaction; MRP4, multidrug resistance protein 4.

DTX chemotherapy in order to reduce or delay the resistance of prostate cancer cells to DTX.

Importantly, the present observation of the re-sensitization of DTX-resistant cells to DTX treatment by anti-androgen treatment may have potential clinical implications. DTX chemotherapy in combination with anti-androgen therapy may achieve beneficial outcomes for patients with CRPC. It was considered that such increased activity of this combined treatment may result from several mechanisms. First, DTX resistance was associated with MRP4 overexpression, the mechanism of which is regulated by androgen signaling. Effective reduction of MRP4 expression and restored sensitivity towards DTX by anti-androgen therapy ultimately achieves the purpose of delaying the resistance to DTX. In addition, one of the important functions of microtubules is the transport of ARs. DTX can impair microtubule function and lead to decreased AR nuclear translocation (31). However, AR nuclear translocation is significantly enhanced following long-term DTX chemotherapy or the occurrence of resistance to DTX in prostate cancer $(3,32)$. Therefore, DTX-induced AR signaling changes may be treated with anti-androgen therapy, and DTX combined with anti-androgen therapy may have a synergistic effect. Finally, prostaglandin E2 (PGE2) performs an important role in the angiogenesis, invasion and metastasis of tumor cells (33). However, PGE2 secretion by prostate cancer cells requires the involvement of MRP4 $(34,35)$. Thus, 
A

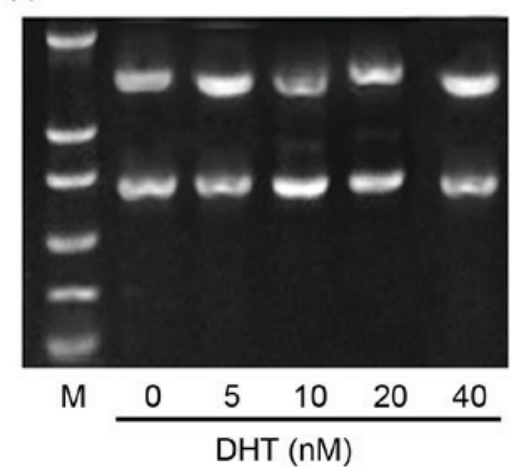

B

GAPDH

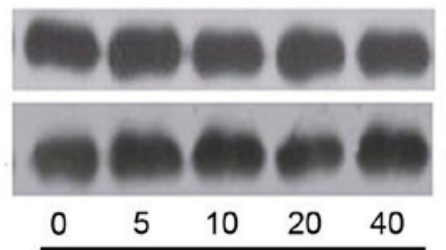

GAPDH

AR

$\mathrm{DHT}(\mathrm{nM})$

Figure 4. The expression of the AR gene was not regulated by androgen levels in docetaxel-resistant (C4-2/D) cells. C4-2/D cells were treated with the indicated concentrations of DHT and subjected to either (A) semi-quantitative reverse transcription-polymerase chain reaction or (B) western blotting to measure AR messenger RNA and protein levels, respectively. AR, androgen receptor; DHT, dihydrotestosterone; M, marker.

A

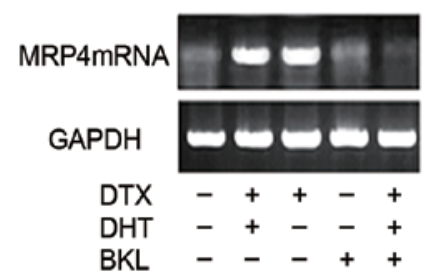

C

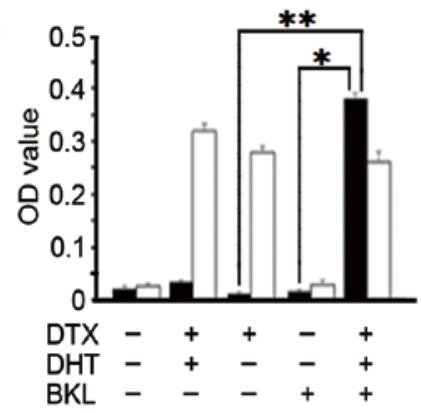

E

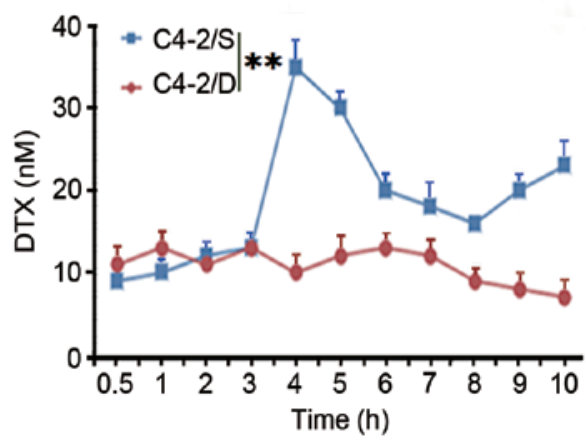

B

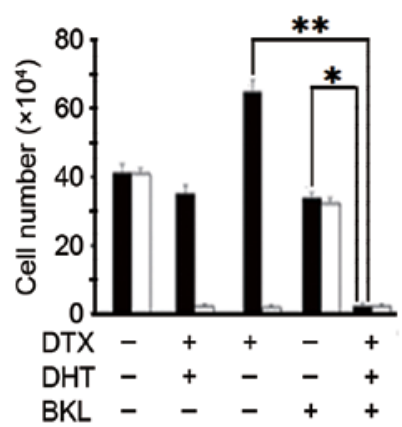

D

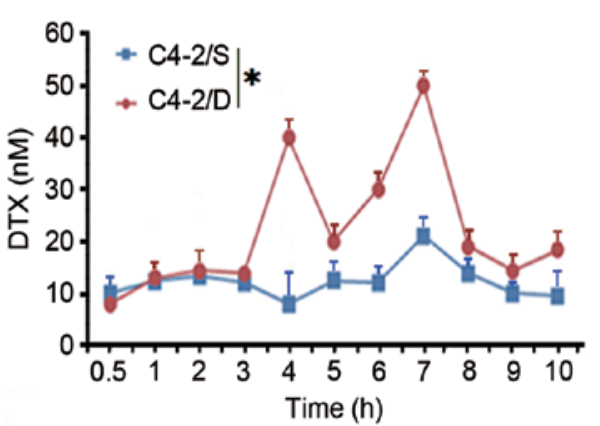

F

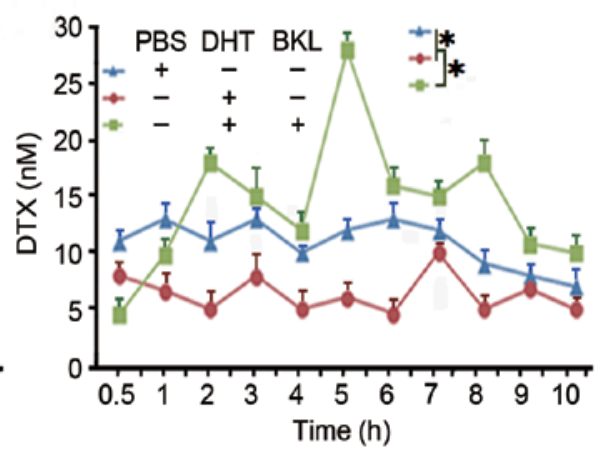

Figure 5. Downregulation of MRP4 expression sensitizes DTX-resistant C4-2/D cells to DTX treatment. (A) DTX-resistant C4-2/D cells were subjected to different treatments as indicated ( $40 \mathrm{nM}$ DTX, $20 \mathrm{nM}$ DHT or $50 \mathrm{nM} \mathrm{BKL}$ ) for 5 days. MRP4 protein levels were determined by western blotting with GAPDH as loading a control. (B) The extent of apoptotic cell death was determined using Annexin V-fluorescein isothiocyanate staining coupled with flow cytometry, following treatment of C4-2/D cells with different drugs, as indicated. (C) Cell viability was assessed by an MTT assay, following the treatment of C4-2/D cells with different drugs, as indicated. (D) C4-2/D and DTX-sensitive C4-2/S cells were treated with $40 \mathrm{nM}$ DTX for the indicated times. The concentration of DTX in extracellular fluids was detected at different time points by HPLC. (E) Cell lysates from C4-2/D or C4-2/S cells treated with $40 \mathrm{nM}$ DTX were extracted and DTX concentrations were tested by HPLC. (F) C4-2/D cells were treated with different drugs as indicated (5 $\mu 1$ PBS, $20 \mathrm{nM} \mathrm{DHT}$ or $50 \mathrm{nM}$ BKL) and the intracellular concentration of DTX was determined by HPLC. ${ }^{*} \mathrm{P}<0.05 ;{ }^{* *} \mathrm{P}<0.001$. DHT, dihydrotestosterone; BKL, bicalutamide; DTX, docetaxel; HPLC, high-performance liquid chromatography; MRP4, multidrug resistance protein 4; OD, optical density. 
the suppression of MRP4 expression by blocking androgens may reduce PGE2 secretion.

In summary, DTX may induce MRP4 expression, and DTX resistance may be associated with the abnormal expression of MRP4 in prostate cancer cells. MRP4 is an androgen responsive- protein whose expression is upregulated by androgen stimulation, but downregulated by anti-androgen treatment. To the best of our knowledge, the present study is the first to propose that DTX chemotherapy may be combined with targeting MRP4 expression to reduce androgen levels, or combined with an anti-androgen approach, which may help delaying or reversing DTX-resistant prostate cancer cells.

\section{Acknowledgements}

The present study was supported by the Hubei Province Health and Family Planning Scientific Research Project of China (grant no., WJ2015MB220). The authors would like to thank Dr Xi Zhou for his comments on the manuscript (Hubei University of Medicine, Shiyan, Hubei, China).

\section{References}

1. Caffo O, De Giorgi U, Fratino L, Alesini D, Zagonel V, Facchini G, Gasparro D, Ortega C, Tucci M, Verderame F, et al: Clinical outcomes of castration-resistant prostate cancer treatments administered as third or fourth line following failure of docetaxel and other second-line treatment: Results of an italian multicentre study. Eur Urol 68: 147-153, 2015.

2. Ramaswamy B and Puhalla S: Docetaxel: A tubulin-stabilizing agent approved for the management of several solid tumors. Drugs Today (Barc) 42: 265-279, 2006.

3. Madan RA, Pal SK, Sartor O and Dahut WL: Overcoming chemotherapy resistance in prostate cancer. Clin Cancer Res 17: 3892-3902, 2011.

4. de Bono JS, Oudard S, Ozguroglu M, Hansen S, Machiels JP, Kocak I, Gravis G, Bodrogi I, Mackenzie MJ, Shen L, et al: Prednisone plus cabazitaxel or mitoxantrone for metastatic castration-resistant prostate cancer progressing after docetaxel treatment: A randomised open-label trial. Lancet 376: 1147-1154 2010.

5. Ryan CJ, Smith MR, Fizazi K, Saad F, Mulders PF, Sternberg CN, Miller K, Logothetis CJ, Shore ND, Small EJ, et al: Abiraterone acetate plus prednisone versus placebo plus prednisone in chemotherapy-naive men with metastatic castration-resistant prostate cancer (COU-AA-302): Final overall survival analysis of a randomised, double-blind, placebo-controlled phase 3 study. Lancet Oncol 16: 152-160, 2015.

6. Loriot Y, Miller K, Sternberg CN, Fizazi K, De Bono JS, Chowdhury S, Higano CS, Noonberg S, Holmstrom S, Mansbach $\mathrm{H}$, et al: Effect of enzalutamide on health-related quality of life, pain, and skeletal-related events in asymptomatic and minimally symptomatic, chemotherapy-naive patients with metastatic castration-resistant prostate cancer (PREVAIL): Results from a randomised, phase 3 trial. Lancet Oncol 16: 509-521, 2015.

7. Kantoff PW, Higano CS, Shore ND, Berger ER, Small EJ, Penson DF, Redfern CH, Ferrari AC, Dreicer R, Sims RB, et al: Sipuleucel-T immunotherapy for castration-resistant prostate cancer. N Engl J Med 363: 411-422, 2010.

8. Parker C, Nilsson S, Heinrich D, Helle SI, O'Sullivan JM, Fosså SD, Chodacki A, Wiechno P, Logue J, Seke M, et al: Alpha emitter radium-223 and survival in metastatic prostate cancer. $\mathrm{N}$ Engl J Med 369: 213-223, 2013.

9. Kunisawa $S$, Tange $C$ and Shimozuma K: Realities in cost-effectiveness analyses: A study of castration-resistant prostate cancer patients using a medical claims database. Springerplus 4: 624, 2015.

10. Zhu Y, Liu C, Armstrong C, Lou W, Sandher A and Gao AC: Antiandrogens Inhibit ABCB1 Efflux and ATPase activity and reverse docetaxel resistance in advanced prostate cancer. Clin Cancer Res 21: 4133-4142, 2015.
11. Hour TC, Chung SD, Kang WY, Lin YC, Chuang SJ, Huang AM, Wu WJ, Huang SP, Huang CY and Pu YS: EGFR mediates docetaxel resistance in human castration-resistant prostate cancer through the Akt-dependent expression of ABCB1 (MDR1). Arch Toxicol 89: 591-605, 2015.

12. Zheng WE, Chen H, Yuan SF, Wu LL, Zhang W, Sun HY and Chen WJ: Overexpression of $\beta I I I-t u b u l i n$ and survivin associated with drug resistance to docetaxel-based chemotherapy in advanced gastric cancer. J BUON 17: 284-290, 2012.

13. Li W, Zhai B, Zhi H, Li Y, Jia L, Ding C, Zhang B and You W: Association of $\mathrm{ABCB} 1, \beta$ tubulin I, and III with multidrug resistance of MCF7/DOC subline from breast cancer cell line MCF7. Tumour Biol 35: 8883-8891, 2014.

14. Hara T, Ushio K, Nishiwaki M, Kouno J, Araki H, Hikichi Y, Hattori M, Imai Y and Yamaoka M: A mutation in beta-tubulin and a sustained dependence on androgen receptor signalling in a newly established docetaxel-resistant prostate cancer cell line. Cell Biol Int 34: 177-184, 2010.

15. Tamaki H, Harashima N, Hiraki M, Arichi N, Nishimura N, Shiina H, Naora K and Harada M: Bcl-2 family inhibition sensitizes human prostate cancer cells to docetaxel and promotes unexpected apoptosis under caspase-9 inhibition. Oncotarget 5: 11399-11412, 2014

16. Arai T, Miyoshi Y, Kim SJ, Akazawa K, Maruyama N, Taguchi T, Tamaki Y and Noguchi S: Association of GSTP1 expression with resistance to docetaxel and paclitaxel in human breast cancers. Eur J Surg Oncol 34: 734-738, 2008.

17. Hendrikx JJ, Lagas JS, Song JY, Rosing H, Schellens JH, Beijnen JH, Rottenberg S and Schinkel AH: Ritonavir inhibits intratumoral docetaxel metabolism and enhances docetaxel antitumor activity in an immunocompetent mouse breast cancer model. Int J Cancer 138: 758-769, 2016.

18. Kelly WK, Halabi S, Carducci M, George D, Mahoney JF, Stadler WM, Morris M, Kantoff P, Monk JP, Kaplan E, et al: Randomized, double-blind, placebo-controlled phase III trial comparing docetaxel and prednisone with or without bevacizumab in men with metastatic castration-resistant prostate cancer: CALGB 90401. J Clin Oncol 30: 1534-1540, 2012.

19. Keppler D: Multidrug resistance proteins (MRPs, ABCCs): Importance for pathophysiology and drug therapy. Handb Exp Pharmacol: 299-323, 2011.

20. Oprea-Lager DE, Bijnsdorp IV, VAN Moorselaar RJ, VAN DEN Eertwegh AJ, Hoekstra OS and Geldof AA: ABCC4 Decreases docetaxel and not cabazitaxel efficacy in prostate cancer cells in vitro. Anticancer Res 33: 387-391, 2013.

21. Savaraj N, Wu C, Wangpaichitr M, Kuo MT, Lampidis T, Robles C, Furst AJ and Feun L: Overexpression of mutated MRP4 in cisplatin resistant small cell lung cancer cell line: Collateral sensitivity to azidothymidine. Int J Oncol 23: 173-179, 2003.

22. Russel FG, Koenderink JB and Masereeuw R: Multidrug resistance protein 4 (MRP4/ABCC4): A versatile efflux transporter for drugs and signalling molecules. Trends Pharmacol Sci 29: 200-207, 2008

23. Zhang YH, Wu Q, Xiao XY, Li DW and Wang XP: Silencing MRP4 by small interfering RNA reverses acquired DDP resistance of gastric cancer cell. Cancer Lett 291: 76-82, 2010.

24. Cai C, Omwancha J, Hsieh CL and Shemshedini L: Androgen induces expression of the multidrug resistance protein gene MRP4 in prostate cancer cells. Prostate Cancer Prostatic Dis 10: 39-45, 2007.

25. Ho LL, Kench JG, Handelsman DJ, Scheffer GL, Stricker PD, Grygiel JG, Sutherland RL, Henshall SM, Allen JD and Horvath LG: Androgen regulation of multidrug resistance-associated protein 4 (MRP4/ABCC4) in prostate cancer. Prostate 68: 1421-1429, 2008.

26. Li YF, Zhang SF, Zhang TT, Li L, Gan W, Jia HT, Xie S, Ji HH and He DL: Intermittent tri-weekly docetaxel plus bicalutamide in patients with castration-resistant prostate cancer: A single-arm prospective study using a historical control for comparison. Asian J Androl 15: 773-779, 2013.

27. Lattanzio L, Tonissi F, Monteverde M, Milano G, Merlano MC and Lo Nigro C: Differential molecular mechanism of docetaxel-octreotide combined treatment according to the docetaxel-resistance status in PC3 prostate cancer cells. Anticancer Drugs 24: 120-130, 2013.

28. Sampath J, Adachi M, Hatse S, Naesens L, Balzarini J, Flatley RM, Matherly LH and Schuetz JD: Role of MRP4 and MRP5 in biology and chemotherapy. AAPS PharmSci 4: E14, 2002. 
29. Lasagna N, Fantappiè O, Solazzo M, Morbidelli L, Marchetti S, Cipriani G, Ziche M and Mazzanti R: Hepatocyte growth factor and inducible nitric oxide synthase are involved in multidrug resistance-induced angiogenesis in hepatocellular carcinoma cell lines. Cancer Res 66: 2673-2682, 2006.

30. Moul JW and Dreicer R: Focusing on testosterone. Urology 78 (5 Suppl): S476-S477, 2011.

31. Zhang G, Liu X, Li J, Ledet E, Alvarez X, Qi Y, Fu X, Sartor O, Dong $\mathrm{Y}$ and Zhang H: Androgen receptor splice variants circumvent AR blockade by microtubule-targeting agents. Oncotarget 6 : 23358-23371, 2015.

32. Thadani-Mulero M, Portella L, Sun S, Sung M, Matov A Vessella RL, Corey E, Nanus DM, Plymate SR and Giannakakou P: Androgen receptor splice variants determine taxane sensitivity in prostate cancer. Cancer Res 74: 2270-2282, 2014.
33. Jain S, Chakraborty G, Raja R, Kale S and Kundu GC: Prostaglandin E2 regulates tumor angiogenesis in prostate cancer. Cancer Res 68: 7750-7759, 2008.

34. Madrigal-Martinez A, Cazaña FJ and Fernández-Martínez yA: Role of intracellular prostaglandin $\mathrm{E}_{2}$ in cancer-related phenotypes in PC3 cells. Int J Biochem Cell Biol 59: 52-61, 2015.

35. Terada $\mathrm{N}$, Inoue $\mathrm{T}$, Kamba $\mathrm{T}$ and Ogawa $\mathrm{O}$ : Novel treatment for prostate cancer targeting prostaglandins. Nihon Rinsho 72: 2141-2146, 2014 (In Japanese). 